\title{
COOPERATION BETWEEN LOCAL GEOGRAPHERS AND RUSSIAN SCIENTISTS IN TURKESTAN (late 19th - early 20th century)
}

\author{
Mamajanov Azamzhon ${ }^{1}$ \\ ${ }^{1}$ Trainee researcher, Institute of History of the Academy of Sciences of Uzbekistan \\ Azamjon.m1991@gmail.com
}

\begin{abstract}
In this article, the author reveals the activities of the Turkestan amateur archeological circle established to conduct archaeological observations, research and partial excavations of artifacts in Turkestan, as well as the views of scientists working in this field. This approach will serve as additional material to previously published works in international scientific circles.

Key words: Turkestan amateur archeological circle, scientific societies, orientalists, archeological observations, excavations, archaeological research, archaeological materials.
\end{abstract}

\section{INTRODUCTION}

Knowledge of your people's history and respect for the cultures of other peoples will strengthen regional solidarity. In particular, the stages of Uzbek statehood and development, as well as various historical, cultural, scientific and practical processes that took place in the 19th and early 20th centuries, were the result of interaction between local culture and neighbouring civilizations. That is why it is important today to look at the roots of historical and cultural ties and interactions.

With the conquest of Central Asia by the Russian Empire and the appointment of the GovernorGeneral of Turkestan among Russian officials, there was an opinion that the country should be studied from a scientific point of view. Although initially a random study of the country was conducted, it later became clear that this process needed to be conducted systematically and holistically. As a result, some scientific societies and institutions began to emerge in the country.

Russian orientalism influenced local historiography with its scientific work. Russian orientalists, in addition to serious research on Central Asian history, have tried to involve local amateur historians in this work. The orientalists who came to Turkestan lived among local historians and amateurs, collected important information and works on Central Asian history and carried out explanatory work on it.

\section{METHODOLOGY AND LEVEL OF STUDY OF THE PROBLEM}

The article is based on methods such as systematising and summarising basic scientific data, historical and comparative analysis, and critical analysis of scientific views and approaches within this chronological period, which focus on the formation and activities of scientific societies and institutions in Turkestan, in particular the Turkestan Archaeological Amateur Circle.

The Turkestan Amateur Archeological Circle occupies a special place among societies engaged in the scientific study of Turkestan. Ancient monuments of Turkestan have long attracted the attention of scientists. Therefore, archeological observations, excavations and partial excavations over relics were conducted during the XIX century. P.I. Lerkh, N.I. Veselovsky, V.A. Zhukovsky [1] and V.V. Zhukovsky work in this area. Bartold, M.S. Andreev, V.L. Vyatkin, A.L. Kuhn. He is associated with the names of A. Semenov, I.T. Poslavsky, N.P. Ostroumov, M.E. Masson [2] and others. The Imperial Archaeological Commission of Central Scientific Institutions, especially the Eastern Branch of the Russian Archaeological Society, as well as the Committee for Historical, Archaeological, Linguistic and Ethnographic Research of Central and Eastern Asia, established in 1903, also paid close attention to the accounting and research of ancient monuments of Turkestan [3].

B. L. Vyatkin began his research in Afrasiab in 1912, and since 1919 he has constantly participated in excavations In the process of M.E. Masson's research, Central Asian Archaeology begins its development as a separate scientific discipline. Although the work of Masson and other researchers during this period focused on the identification, preservation and partial restoration of monuments, new archaeological research methods were developed.

Before the 1930s, there was an insufficient experience in the study, description and classification of material finds and based on this experience, important conclusions about the history of Central Asian cities could be drawn. In particular, with some stops on the ruins of Afrosiab in 1905, 1907, 1912 and later, V.L. Vyatkin's research resulted in many materials and numismatic objects and on their basis a special work was published. 
However, the lack of sufficient experience in analyzing and describing the archaeological materials obtained did not allow us to draw important scientific conclusions on this issue. Later in his analysis of the problem, Shishkin came to the conclusion that "... the reason is that archaeological methods are not yet sufficiently mastered, and from a stratigraphic point of view, little attention is paid to cultural layers" [5].

According to the analysis of sources, well-known scientists mobilized from Russia can be divided into two groups. The first group of scientists diligently fulfilled the task of their government mastered the incalculable wealth of the country, the second group studied life, underground and surface resources of Turkestan from the real scientific point of view, and made a great contribution to the development of science and the peoples of the world. But this category of scientists was second to none in number, and even the most prominent Russian scientists were most prone to colonial ideas and aggressive wars.

After the occupation of Central Asia, the Russian Empire actively sought to systematically study the country and its conditions to obtain greater economic benefits from the newly occupied lands and ensure the dependence of the local population. However, the lack of such institutions, bodies and specialists in the country initially made it necessary to study the region through the activities of various scientific societies. As a result, the Central Asian Scientific Society, the Turkestan Branch of the Russian Imperial Geographical Society, the Turkestan Amateur Archaeological Circle, the Turkestan Agricultural Society and other scientific societies were established in the country.

Academician V.V. Bartold wrote about the beginning of the study of Central Asia: "Soon after the establishment of the Governor-General of Turkestan, scientific activities began. The main purpose of studying the country is to learn about geographical, natural and statistical relationships. The population and its past also have meaning "[6]. The activities of scientific societies in Central Asia played an important role in the development of the region by the Russian Empire.

According to B.V. Lunin, a well-known historian of the history of religious societies operating in Central Asia, the materials collected by these scientific societies have also generated great interest in contemporary research.

\section{MAIN PART}

Archaeological excavations in Turkestan have not been conducted independently for a long time. Systematic archaeological research in this process, which continued until 1886, is one of them. Speaking on December 11, 1893, at a meeting on anthropology, ethnography and natural science, N.P. Ostroumov called for further archaeological research and said: "There are many archaeological monuments in our country. They should be studied". V.V. Bartold also acquainted participants of a meeting with preliminary results of archeological searches. The speeches by N. Ostroumov and V. Bartold were well received by the meeting participants. The Statutes of the Circle were approved on 31 October 1895. The Turkestan amateur archaeological circle was opened on 14 December 1895. The club's activities were conducted in the following areas:

a) to get acquainted with the monuments of Turkestan;

b) draw up an archaeological map of the country;

c) preservation of archeological monuments;

d) archeological excavations;

d) Processing of local archaeological materials.

On 22 December 1896, a meeting of the Turkestan Amateur Archaeological Circle was held, where a list of 47 members was drawn up.

Later the circle had 108 members, including V.L. Vyatkin, D.M. Levshin, N.S. Likoshin, V.F. Oshanin and other well-known people. The influence of the advanced Russian intelligentsia in the circle was strong, and they began their scientific research with respect for history and ancient monuments of Central Asia. Archaeological issues were discussed at the meetings of the Circle. On December 15, 1896, a telegram was sent from Tashkent to the Turkestan amateur archaeological circle in the Russian society of archeologists. The Turkestan amateur archeological circle set itself the tasks at this time.

N.I. Veselovsky, V.V. Bartold, V.L. Vyatkin and many other famous scientists of that time, who were considered to be leading figures in Russian social and humanities sciences, included local historians, collectors (known, collectors of rare archaeological artifacts) in their research on Turkestan and they received excellent practical instructions, valuable labels, hints from lovers of antiquity, which they noted in their memories and even in their scientific works.

The contribution of local intellectuals to the study of Central Asian archaeology before the October coup in Russia is also noteworthy.

In particular, Tashkent merchant Akram Polvon Askarov is known for his large collection of antiques from various periods. He took part in several excavations in Turkestan under the supervision of Veselovsky. According to N.I.Veselovsky, Akram Askarov had extensive experience in collecting ancient coins, and Akram Askarov greatly helped him in studying Afrosiab and surrounding monuments, historical monuments in the Bukhara, Syrdarya and Fergana regions [8]. 
According to Professor Uvarnitsky's article "Archaeological collection of Akrom Askarov" published in "Turkestanskie vedomosti" in the 31st issue of 1892, there were 17 gold, 1370 silver, 13274 copper coins, stone hammers of the Neolithic period and copper kettles. There were ceramic human statues, amulets, copper, ceramics and similar historical artefacts collected in various places [9].

Particularly noteworthy is the letter of recommendation from N.I. Veselovsky to the commission of the Russian Archaeological Society on awarding Akram Askarov for his contribution to the development of Turkestan archaeology. In the presentation, the author praised the work of Akram Askarov on collecting and archaeological excavations: "In Turkestan there are many antique dealers, and Russian collectors often work for a profit. But although Akram Askarov is actively interested in archaeology, he does not want to benefit from it but pays for the development of archaeology at his own expense ... During my archeological trips to the Syrdarya, Fergana and Bukhara Emirates he did a lot for me. I knew nothing and could not achieve success "[10].

In 1887, the Russian Archaeological Society awarded Akram Askarov a silver medal for his contribution to archeology. According to press reports of that time, he was "a well-known collector of rare archaeological artifacts from Turkestan and a member of the Paris Scientific Archaeological Society" [11].

One more enthusiast of studying the ancient Turkestan peoples is Abu Said Mahsum, son of Mullah Kazi ibn Mullah Abdurashid, a calligrapher from Samarkand. He worked as a teacher at the Shaibanikhan Madrassah in Samarkand. N.I. Veselovsky admitted about this printer that "in the person of Mirza Abu Said Makhsum, we had the opportunity to meet one of the most educated connoisseurs of Muslim literature in Samarkand".

The famous orientalist W.W. Bartold also knew Abu Said Makhsum personally and received various certificates, documents and donations from him from the time of the Timurid Sultan Shahruh Mirza to the last Sheibanid representatives.

At the end of the first decade of the twentieth century, the search for the remains of the Ulugbek Observatory, led by V.L. Vyatkin, was a great success. V.A. According to Shishkin, "... excavations will culminate in the discovery of the Ulugbek Observatory, one of the cultural masterpieces of the peoples of Central Asia, a world-class discovery that has provoked heated debate and discussion in Russian and foreign scientific publications" [14].

Abu Said Makhsum is also credited with the discovery of the Observatory, which has caused a stir throughout the world. Abu Said Makhsum V.L. Vyatkin was shown the hill on which the observatory was located. We should not forget that since colonial ideology focused only on Russian scientists who were the first in all fields of science, the name of Abu Said Makhsum was not mentioned at the opening of the observatory, but only V.L. Vyatkin.

\section{CONCLUSION}

In conclusion, the following should be noted:

It is clear from the above data that the membership and activities of many of the governors-general in scientific societies are not because they hold any position, but to the fact that most members of society work in a scientific field other than military or diplomatic;

Foreign scientists are also invited to join the circle. These include the German astronomer Franz Schwarz, who dedicated his book Turkestan, the Cradle of the Indo-Herman Nations, to this issue;

Representatives of local intellectuals also took part in the study of Turkestan archaeology, which began in the last quarter of the 19th century and began to accumulate certain skills and experience.

\section{References:}

1. Zhukovskiy V.A. Antiquities of Transcaspian region. The ruins of old Merv. - SPb., 1894. - 230 p. [ Zhukovskiy V.A. Razvaliny Starogo Merva // Drevnosti Zakaspiyskoy oblasti. - SPb., 1894. - 230 s.].

2. Masson M.E. Short essays on the history of the study of Central Asia in archeological relations // TR. SAGU. - Tashkent, 1956. - Vyp. LXXXI. - S.11-12. [Masson M. E. Kratkie ocherki po istorii izucheniya Central'noj Azii v arheologicheskih otnosheniyah//TR. SAGU. - Tashkent, 1956. - Vyp. LXXXI. -S. 11-12.].

3. G'ulomov Ya. Archeology in Uzbekistan. "Red Uzbekistan", "Truth of the East", T .: Uzbekistan Surkh, 1956, p. 7-8. [Gulomov Ya. Arheologiya v Uzbekistane // "Krasnyj Uzbekistan", " Pravda Vostoka". - T.: Uzbekistan, 1956, s. 7-8.].

4. Vyatkin V.L. Afrasiab is a city in Samarkand. - Tashkent, 1927. - 64 p. [Vyatkin V. L. Afrasiabgorod v Samarkande. - Tashkent, 1927. - 64 S.]. 
5. Shishkin V. A. Vasiliy Lavrent'evich Vyatkin (For the thirtieth anniversary from the date of death) // the YMCA. - Tashkent, 1963. - Issue 4. - P. 148. [Shishkin V.A. Vasiliy Lavrentevich Vyatkin. (K tridtsatiletiyu so dnya smerti) // IMKU. - Tashkent, 1963. - Vyp. 4. - S. 148].

6. Lunin B.V. From the History of Russian Oriental Studies and Archaeology in Turkestan. Turkestan circle of fans of archeology (1895-1917). - T., 1958. - P.12. [Lunin B.V. Iz istorii russkogo vostokovedeniya $i$ archeologii $v$ Turkestane. Turkestanskiy krujok lyubiteley archeologii (1895-1917gg.). - T., 1958.-S.12.].

7. National Encyclopedia of Uzbekistan. State Scientific Publishing House, 2000. - P.234-235. ["O’zbekiston milliy ensiklopediyasi”. Davlat ilmiy nashriyoti, 2000. - B.234.].

8. Nabiev A. Historical Local Lore. - T .: “Teacher”, 1996. P.33. [Nabiev A. Tarihiy o'lkashunoslik. - T.: “O'qituvchi”, 1996. B.33.].

9. Lunin, B.V. About numismatic collection of the Uzbek antiquities collector Akram Askarov (on archival data) // INCU. Vyp. 5. -T: Fan, 1964. [Lunin B.V.O Numizmaticheskoy kollektsii uzbekskogo sobiratelya drevnostey Akrama Askarova (po arxivnım dannım) // IMKU. Vip. 5. -T: Fan, 1964.

10. «Turkestanskie Vedomosti», 1912, № 46.

11. Muminov I.M. From the history of the development of social-philosophical mislee in Uzbekistan contessa XIX - early XX centuries Tashkent, Gosizdat, 1957. - P. 124. [Muminov I.M. Iz istorii razvitiya obshestvenno-filosofskoy misli v Uzbekistane kontsa XIX - nachala XX vv.Tashkent, Gosizdat, 1957. C.124.].

12. Bartold V.V. Report on business trip to Turkestan // ZVORAO. T.XV, SPb., 1904. [Bartold V.V. Otchet o komandirovke v Turkestan // ZVORAO. T.HV, S. Pb., 1904.].

13. Shishkin, V.A. Ulugbek's observatory and its research // Proceedings of Institute of history and archeology of Academy of Sciences of the Uzbek SSR. T. 5. Tashkent, 1953. [Shishkin V.A. Observatoriya Ulugbeka i eyo issledovanie // Trudy Instituta istorii i archeologii AN UzSSR. T. 5. Tashkent, 1953]. 